\title{
A New Method for the Oxazolidinone Key Intermediate of Linezolid and its Formal Synthesis
}

\author{
HoonGyu Park, Bojung Kim, Daeil Bae, Byungjo Lim, Misun Ko, Sehan Oh, and Hakwon Kim* \\ Department of Applied Chemistry, College of Applied Sciences, Kyung Hee University, Gyeonggi-do 446-701, Korea \\ *E-mail:hwkim@khu.ac.kr \\ Received December 30, 2011, Accepted January 26, 2012
}

Key Words : Oxazolidinone, Linezolid, (5-Hydroxymethyl) oxazolidinone, Intramolecular cyclization

In recent years, the incidence of increase in bacterial resistance to a number of available antimicrobial agent, such as $\beta$-lactam (penicillin) antibiotics, macrolides, quinolones and vancomycin, has become a critical issue. For instance, vancomycin, an antibiotic generally considered as the ultimate solution against serious gram-positive infections, has been found ineffective on the vancomycin-resistant enterococci (VRE). Therefore, there has been an increased need for totally new agents for effective therapy of grampositive infections by antimicrobial-resistant species. In the search for a new antimicrobial agent, several kinds of synthetic organic compounds have been focused. Among these new compounds, an oxazolidinone was first suggested as a candidate for use as a new antimicrobial agent by Du Pont scientists in 1978. With several biological assay tests, it was claimed that oxazolidinone compounds represent a new class of antimicrobial agents having a unique structure and activity against gram-positive pathogenic bacteria.

After early discoveries of the new oxazolidinone antibacterial compounds demonstrated weak in vitro antimicrobial activity, further studies have been encouraged to develop the lead compound DuP-721 (Figure 1) as a drug candidate. ${ }^{1}$ Even though DuP-721 showed promising activity, advanced clinical testing was discontinued due to its toxicity. As a result, instead of the early lead compound, two new oxazolidinone compounds, eperezolid and linezolid (Figure 1), have been developed, both of which are active in vitro and in vivo against methicillin-resistant Staphylococcus aureus, penicillin-resistant Streptococcus pneumonise and vancomycin-resistant Enterococcus faecium. ${ }^{2,3}$ A New Drug Application has been filed with the Food and Drug Administration (FDA, USA) for linezolid, presently being sold in the US under the brand name of "Zyvox". It is known that the mechanism of action of this oxazolidinone antimicrobial agent is based on the inhibition of bacterial protein synthesis. ${ }^{4}$ Since the first synthesis of the oxazolidinone anti-

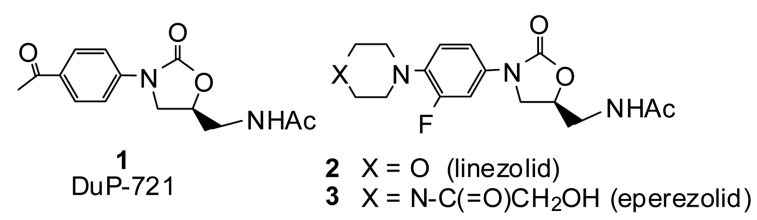

Figure 1. Structure of oxazolidinone antibacterial compounds. microbial agent DuP-721 was reported in the 1980's, numerous new oxazolidinone compounds have been synthesized and several new synthetic methods have been reported. ${ }^{5}$

Several synthetic methods have been studied and developed; however, in response to increasing concern about its antimicrobial activity, comparatively fewer studies on the development of the new synthetic method to provide the oxazolidinone compound have been performed. Hence, there is a clear need for the development of a new synthetic method for an oxazolidinone; in order to study this method of oxazolidinone antimicrobial agents, especially linezolid, we have utilized the epoxide intermediate, which has been developed in our research group. In this paper, a new pathway to the key intermediate oxazolidinone antibiotics is described, and the formal synthesis of linezolid is demonstrated.

From a review of the previous syntheses it was determined that most methods for preparing an oxazolidinone ring were closely related to the intermolecular reaction. During the study of epoxide chemistry, it was discovered that an acidmediated epoxide ring opening of an epoxy carbamate yielded the oxazolidinone compound through an intramolecular reaction. ${ }^{6}$ Our synthetic strategy for linezolid, including the formation of the oxazolidinone ring, is outlined briefly in Scheme 1 .

According to Baldwin's Rule, the formation of the smaller ring over the larger ring from this intramolecular cyclization could be properly explained. One of the detailed mechanisms of this reaction could be proposed in Scheme 2. First, $\mathrm{CF}_{3} \mathrm{COOH}$, that is the best reagent for an intramolecular cyclization of an epoxy carbamate compound, might act as a Lewis acid liberating a proton to be coordinated on the epoxide oxygen atom. Now it is probable that the protoncoordinated epoxide could be easily attacked by a neighboring group, another oxygen atom of the carbamate group.
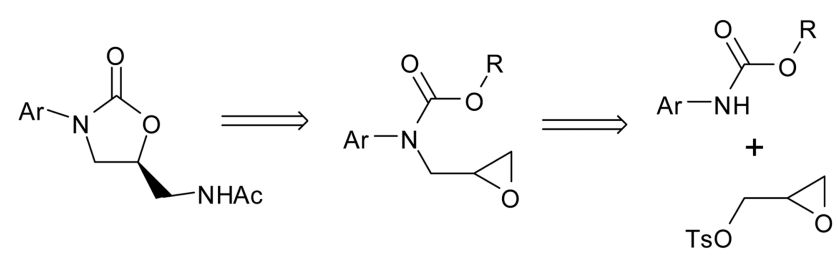

Scheme 1. Synthetic strategy for the oxazolidinone compounds. 
<smiles>[R]OC(=O)N([Al])CC1CO1</smiles>



Scheme 2. Proposed mechanism of intramolecular cyclization of the epoxy carbamate.

By the subsequent detachment of the tertiary butyl group, resulting in the restoration of the carbonyl group, an oxazolidinone compound was formed.

Owing to the possession of only one enantiomer with effective antimicrobial activity, a synthesis of a chiral oxazolidinone, starting with a chiral glycidyl tosylate, was attempted. However, this asymmetric synthesis did not result in the desired optically pure compound. From the data of the optical rotatory value of linezolid synthesized by this method, it was assumed that there was partial racemization in one or more steps. It is likely that the asymmetric coupling reaction of the carbamate $\mathbf{8}$ with a chiral glycidyl tosylate might be considered as partial racemization. From the literature, ${ }^{8}$ a partial racemization during the reaction of the chiral allylic epoxide with a nucleophile could be explained by the Payne rearrangement; however, a full explanation should be established (Scheme 3).

At this point, a more detailed explanation, as well as a solution of the problem of how to make a chiral oxazolidinone through this route, is still under investigation.

Our synthesis of linezolid began with the morpholinyl aniline 4, using an available starting material. For both the protection and the activation of the amino group, the aniline derivative was treated with di-t-butyl dicarbonate in the
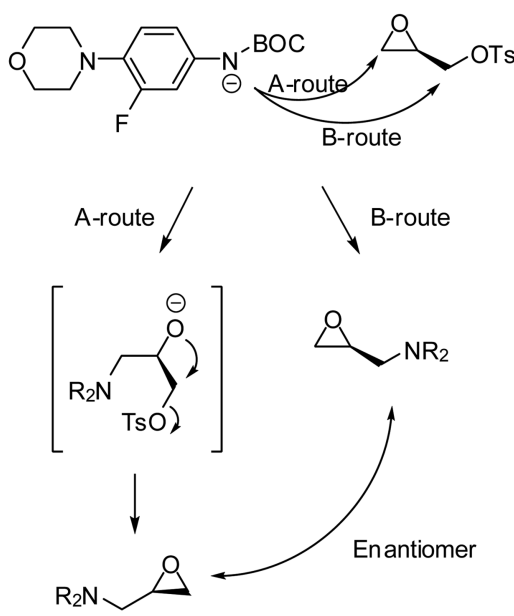

Scheme 3. Proposed mechanism of partial racemization via Payne rearrangement.

presence of $\mathrm{La}\left(\mathrm{NO}_{3}\right)_{3} \cdot 6 \mathrm{H}_{2} \mathrm{O}$ to give an $\mathrm{N}-\mathrm{BOC}$ aniline as a yellow solid in a $91 \%$ yield. In this step, La-catalyzed method showed higher yield and shorter reaction time than conventional methods using a base, such as $\mathrm{Et}_{3} \mathrm{~N}{ }^{8}{ }^{8}$ Next, the coupling reaction of an N-BOC aniline 5 with a racemic glycidyl tosylate was achieved under basic conditions (potassium $t$-butoxide in DMF) to give a resulting epoxy carbamate 6 as yellowish oil. In the presence of trifluoroacetic acid in THF, an oxazolidinone key intermediate 7 was produced as a white solid in an adequate yield (two steps $86 \%)$.

In order to complete the synthesis of linezolid from a 5(hydroxymethyl)-oxazolidinone intermediate 7, further transformations were undertaken according to the previous procedure. $^{2}$ The hydroxy group of the oxazolidinone intermediate was mesylated to be activated for displacement, followed by treatment with sodium azide to give the azide intermediate 9. The subsequent Pd-catalyzed hydrogenolysis of azide afforded the amine $\mathbf{1 0}$, followed by acetylation with acetic anhydride to provide the racemic linezolid, which was identified by comparison with the literature data. Chiral linezolid (2) could be gotten from a chiral amino intermedaite10


Scheme 4. Formal total synthesis of Linezolid. (a) $(\mathrm{BOC})_{2} \mathrm{O}, \mathrm{La}\left(\mathrm{NO}_{3}\right)_{3} \cdot 6 \mathrm{H}_{2} \mathrm{O}, \mathrm{CH}_{3} \mathrm{CN}, \mathrm{rt}, 1 \mathrm{~h}, 91 \%$; (b) glycidyl tosylate, $\mathrm{DMF}, \mathrm{KOBu}$, 0 ${ }^{\circ} \mathrm{C}, 42 \mathrm{~h}$; (c) $\mathrm{CF}_{3} \mathrm{COOH}, \mathrm{CH}_{2} \mathrm{Cl}_{2}$, rt, 4 h, 86\% (two steps yield); (d) MsCl, TEA, $\mathrm{CH}_{2} \mathrm{Cl}_{2}$, rt, $2.5 \mathrm{~h}, 96 \%$; (e) $\mathrm{NaN}_{3}, \mathrm{DMF}, 80{ }^{\circ} \mathrm{C}, 3.5 \mathrm{~h}, 93 \%$; (f) $10 \% \mathrm{Pd} / \mathrm{C}, \mathrm{H}_{2} 12$ bar, EtOAc, rt, 12 h, 87\%; (g) 1) Di-P-Toluoyl-L-tartaric acid, DMSO, 3 h, rt. 2) $\mathrm{Na}_{2} \mathrm{CO}_{3}, \mathrm{CH}_{2} \mathrm{Cl}_{2}, 1$ h, rt. 3 ) (Ac) $)_{2} \mathrm{O}$, $\mathrm{CH}_{2} \mathrm{Cl}_{2}, 1 \mathrm{~h}, \mathrm{rt}, 28 \%$ (three steps yield). 
in $80 \%$ ee , which was prepared form the resolution of racemic intermediate 10 with di- $p$-toluoyl-L-tartaric acid.

In conclusion, we have developed a new and reliable synthetic methodology, the $\mathrm{CF}_{3} \mathrm{COOH}$-mediated intramolecular cyclization of an epoxy carbamate, for an oxazolidinone compound. This new pathway was demonstrated for the formal synthesis of oxazolidione antibiotics, linezolid.

\section{Experimental Section}

\section{3-Fluoro-4-morpholin-4-yl-phenyl)carbamic acid tert-} butyl ester (5). To a solution of 3-fluoro-4-morpholin-4-ylphenylamine (4) $(0.5 \mathrm{mmol}, 0.1 \mathrm{~g})$ and $\mathrm{La}\left(\mathrm{NO}_{3}\right)_{3} \cdot 6 \mathrm{H}_{2} \mathrm{O}$ $(25.5 \mu \mathrm{mol}, 0.011 \mathrm{~g})$ in $\mathrm{CH}_{3} \mathrm{CN}(1.5 \mathrm{~mL})$ was added di-tbutyl dicarbonate $(0.8 \mathrm{mmol}, 0.2 \mathrm{~mL})$. The reaction mixture was stirred at room temperature for $1 \mathrm{~h}$. The mixture was concentrated, which was poured into water and extracted with $\mathrm{CH}_{2} \mathrm{Cl}_{2}$. The combined organic layers were dried over $\mathrm{MgSO}_{4}$. Solvent was removed in vacuo and the product was purified by recrystallization (ethyl acetate, hexane) to give a white solid. Yield 91\%.

The product was identified by comparing data with literature. $^{2}$

${ }^{1} \mathrm{H}-\mathrm{NMR}\left(300 \mathrm{MHz}, \mathrm{CDCl}_{3}\right) \delta 1.53(\mathrm{~s}, 9 \mathrm{H}), 3.02(\mathrm{t}, 4 \mathrm{H}, J$ $=4.8 \mathrm{~Hz}), 3.86(\mathrm{t}, 4 \mathrm{H}, J=4.6 \mathrm{~Hz}), 6.37(\mathrm{brs}, 1 \mathrm{H}), 6.83-6.94$ $(\mathrm{m}, 2 \mathrm{H}), 7.25-7.31(\mathrm{~m}, 1 \mathrm{H})$.

3-(3-Fluoro-4-morpholin-4-yl-phenyl)-5-hydroxymethyl-oxazolidin-2-one (7). 3-Fluoro-4-morpholin-4-yl-phenyl)carbamic acid tert-butyl ester (5) (3.4 mmol, $1.0 \mathrm{~g})$ and potassium tertiary-butoxide $(7.4 \mathrm{mmol}, 0.8 \mathrm{~g})$ in $N, N$ dimethyl formamide (DMF, $34 \mathrm{~mL}$ ) were stirred at $0{ }^{\circ} \mathrm{C}$ for $30 \mathrm{~min}$. After addition of a solution of racemic glycidyl tosylate $(4.4 \mathrm{mmol}, 1.0 \mathrm{~g})$ in DMF $(4 \mathrm{~mL})$, the mixture was stirred at $0{ }^{\circ} \mathrm{C}$ for $42 \mathrm{~h}$. After evaporation of DMF, the residue was poured into water and extracted with $\mathrm{CH}_{2} \mathrm{Cl}_{2}$. The combined organics were dried over $\mathrm{MgSO}_{4}$. Solvents were removed in vacuo. Crude product 6 was to be used in the next reaction. A mixture of crude product $\mathbf{6}$ and trifluoroacetic acid (16.9 mmol, $1.3 \mathrm{~mL})$ in $\mathrm{CH}_{2} \mathrm{Cl}_{2}(17 \mathrm{~mL})$ was stirred at room temperature. After stirring for $4 \mathrm{~h}$, the solution was quenched with water and extracted with $\mathrm{CH}_{2} \mathrm{Cl}_{2}$. The combined organic layers were washed with brine and dried over $\mathrm{MgSO}_{4}$. Solvent was removed in vacuo and the product was purified by column chromatography (ethyl acetate, hexane) to give a white solid. Yield $86 \%$. The product was identified by comparing data with literature. ${ }^{2}$

Identification data of 6 : ${ }^{1} \mathrm{H}$ NMR $\left(300 \mathrm{MHz}, \mathrm{CDCl}_{3}\right) \delta$ $1.45(\mathrm{~s}, 9 \mathrm{H}), 2.50-2.54(\mathrm{~m}, 1 \mathrm{H}), 2.80(\mathrm{t}, 1 \mathrm{H}, J=4.6 \mathrm{~Hz})$, 3.04-3.09 (m, 4H), 3.19-3.27 (m, 1H), 3.50 (dd, 1H, $J=6.0$, 14.0 Hz), 3.84-3.93 (m, 5H), 6.83-7.03 (m, 3H).

${ }^{13} \mathrm{C}$ NMR $\left(75 \mathrm{MHz}, \mathrm{CDCl}_{3}\right) \delta 27.35,44.77,49.38,49.97$ $(\mathrm{d}, J=3.1 \mathrm{~Hz}), 51.73,65.97,79.84,114.32(\mathrm{~d}, J=22.3 \mathrm{~Hz})$, $117.28(\mathrm{~d}, J=3.7 \mathrm{~Hz}), 121.80,136.45(\mathrm{~d}, J=9.9 \mathrm{~Hz})$, 137.17 (d, $J=8.6 \mathrm{~Hz}), 153.40,153.94$ (d, $J=244.8 \mathrm{~Hz})$.

IR (KBr) 2794, 1699, $1512 \mathrm{~cm}^{-1}$.

7: ${ }^{1} \mathrm{H}-\mathrm{NMR}\left(300 \mathrm{MHz}, \mathrm{CDCl}_{3}\right) \delta 3.05(\mathrm{t}, 4 \mathrm{H}, J=4.4 \mathrm{~Hz})$, 3.73-3.77 (m, 1H,) $3.87(\mathrm{t}, 4 \mathrm{H}, J=4.2 \mathrm{~Hz}), 3.92-4.03(\mathrm{~m}$,
$3 \mathrm{H}), 4.71-4.77(\mathrm{~m}, 1 \mathrm{H}), 6.93(\mathrm{t}, 1 \mathrm{H}, J=9.0 \mathrm{~Hz}) 7.25(\mathrm{~d}, 1 \mathrm{H}$, $J=8.8 \mathrm{~Hz}), 7.44(\mathrm{dd}, 1 \mathrm{H}, J=2.2,12.0 \mathrm{~Hz})$.

Methanesulfonic acid 3-(3-Fluoro-4-morpholin-4-ylphenyl)-2-oxo-oxazolidin-5-ylmethyl ester (8). To a solution of 3-(3-fluoro-4-morpholin-4-yl-phenyl)-5-hydroxymethyl-oxazolidin-2-one (7) $(0.3 \mathrm{mmol}, 0.1 \mathrm{~g})$ in $\mathrm{CH}_{2} \mathrm{Cl}_{2}$ $(3.5 \mathrm{~mL})$ was added triethylamine $(0.7 \mathrm{mmol}, 0.1 \mathrm{~mL})$ and it was stirred at $0{ }^{\circ} \mathrm{C}$ for $40 \mathrm{~min}$. After addition of methane sulfonyl chloride $(0.5 \mathrm{mmol}, 40.0 \mu \mathrm{L})$, the solution was stirred at room temperature for $2.5 \mathrm{~h}$, and then it was quenched with water and extracted with $\mathrm{CH}_{2} \mathrm{Cl}_{2}$. The combined organic layers were washed with brine and dried over $\mathrm{MgSO}_{4}$. Solvent was removed in vacuo and the product was purified by recrystallization (ethyl acetate, hexane) to give a white solid. Yield $96 \%$.

The product was identified by comparing data with literature. $^{2}$

${ }^{1} \mathrm{H}-\mathrm{NMR}\left(300 \mathrm{MHz}, \mathrm{CDCl}_{3}\right) \delta 3.06(\mathrm{t}, 4 \mathrm{H}, J=4.6 \mathrm{~Hz})$, $3.11(\mathrm{~s}, 3 \mathrm{H}) 3.88(\mathrm{t}, 4 \mathrm{H}, J=4.4 \mathrm{~Hz}), 3.92-3.95(\mathrm{~m}, 1 \mathrm{H}), 4.12$ (t, $1 \mathrm{H}, J=9.0 \mathrm{~Hz}), 4.46(\mathrm{dd}, 1 \mathrm{H}, J=3.9,7.9 \mathrm{~Hz}), 4.91-4.92$ (m, 1H), 5.30 (brs, 1H), 6.94 (t, 1H, $J=8.9 \mathrm{~Hz}), 7.11(\mathrm{~d}, 1 \mathrm{H}$, $J=7.3 \mathrm{~Hz}), 7.46(\mathrm{dd}, 1 \mathrm{H}, J=2.4,11.9 \mathrm{~Hz})$.

5-Azidomethyl-3-(3-fluoro-4-morpholin-4-yl-phenyl)oxazolidin-2-One (9). Methanesulfonic acid 3-(3-fluoro-4morpholin-4-yl-phenyl)-2-oxo-oxazolidin-5-ylmethyl ester (8) $(1.1 \mathrm{mmol}, 0.4 \mathrm{~g})$ and sodium azide $(1.7 \mathrm{mmol}, 0.1 \mathrm{~g})$ in DMF $(11 \mathrm{~mL})$ were stirred at $80{ }^{\circ} \mathrm{C}$ for $3.5 \mathrm{~h}$. After evaporation of $\mathrm{DMF}$, the residue was poured into water and extracted with $\mathrm{CH}_{2} \mathrm{Cl}_{2}$. The combined organics were dried over $\mathrm{MgSO}_{4}$. Solvents were removed in vacuo and the product was purified by recrystallization (ethyl acetate, hexane) to give a white solid. Yield 93\%.

The product was identified by comparing data with literature. $^{2}$

${ }^{1} \mathrm{H}-\mathrm{NMR}\left(300 \mathrm{MHz}, \mathrm{CDCl}_{3}\right) \delta 3.06(\mathrm{t}, 4 \mathrm{H}, J=4.6 \mathrm{~Hz})$, $3.61(\mathrm{dd}, 1 \mathrm{H}, J=4.2,9.0 \mathrm{~Hz}), 3.71(\mathrm{dd}, 1 \mathrm{H}, J=4.6,8.6 \mathrm{~Hz})$, $3.80-3.83(\mathrm{~m}, 1 \mathrm{H}), 3.87(\mathrm{t}, 4 \mathrm{H}, J=4.4 \mathrm{~Hz}), 4.05(\mathrm{t}, 1 \mathrm{H}, J=$ $8.8 \mathrm{~Hz}), 4.76-4.80(\mathrm{~m}, 1 \mathrm{H}), 6.94(\mathrm{t}, 1 \mathrm{H}, J=9.0 \mathrm{~Hz}), 7.12$ (d, $1 \mathrm{H}, J=8.8 \mathrm{~Hz}), 7.44(\mathrm{dd}, 1 \mathrm{H}, J=2.4,11.9 \mathrm{~Hz})$.

5-(Aminomethyl)-3-(3-fluoro-4-morpholinophenyl)oxazolidin-2-one (10). To a solution of 5-azidomethyl-3-(3fluoro-4-morpholin-4-yl-phenyl)-oxazolidin-2-one (9) (2.3 mmol, $0.7 \mathrm{~g})$ in ethyl acetate $(23 \mathrm{~mL})$ was added $10 \% \mathrm{Pd} / \mathrm{C}$ $(0.1 \mathrm{mmol}, 0.1 \mathrm{~g})$. The mixture was stirred at room temperature under 12 bar of $\mathrm{H}_{2}$. After $12 \mathrm{~h}$, the mixture was filtered through celite, concentrated in vacuo and purified by recrystallization (ethyl acetate, hexane) to give a white solid. Yield $87 \%$.

The product was identified by comparing data with literature. $^{2}$

${ }^{1} \mathrm{H}-\mathrm{NMR}\left(300 \mathrm{MHz}, \mathrm{CDCl}_{3}\right) \delta$ 2.94-3.15 (m, 6H), 3.80$3.89(\mathrm{~m}, 5 \mathrm{H}), 3.99(\mathrm{t}, 1 \mathrm{H}, J=8.6 \mathrm{~Hz}), 4.68(\mathrm{brs}, 1 \mathrm{H}), 6.93(\mathrm{t}$, $1 \mathrm{H}, J=9.2 \mathrm{~Hz}), 7.14(\mathrm{~d}, 1 \mathrm{H}, J=8.6 \mathrm{~Hz}), 7.46(\mathrm{dd}, 1 \mathrm{H}, J=$ $2.4,12.1 \mathrm{~Hz})$.

$\mathrm{N}$-[3-(3-Fluoro-4-morpholin-4-yl-phenyl)-2-oxo-oxazolidin-5-yl-methyl]-acetamide (2). To a solution of 5(aminomethyl)-3-(3-fluoro-4-morpholinophenyl)oxazolidin- 
2-one (10) (0.3 mmol, 0.1 g) in DMSO (4 mL) was added dip-toluoyl-L-tartaric acid $(0.1 \mathrm{mmol}, 52 \mathrm{mg})$. The mixture was stirred at room temperature for $3 \mathrm{~h}$. After filtration, a white solid was dried in oven $\left(70{ }^{\circ} \mathrm{C}\right)$, dissolved in $\mathrm{CH}_{2} \mathrm{Cl}_{2}$ and water, and then sodium carbonate $(0.3 \mathrm{mmol}, 51 \mathrm{mg})$ was added. Organic layer was separated, dried over $\mathrm{MgSO}_{4}$ and concentrated in vacuo to give a white solid. To a mixture of a chiral amine 10 and pyridine $(0.3 \mathrm{mmol}, 27 \mu \mathrm{L})$ in ethyl acetate $(4 \mathrm{~mL})$ was added acetic anhydride $(0.3 \mathrm{mmol}, 32$ $\mu \mathrm{L})$ and then it was stirred at room temperature for $1 \mathrm{~h}$. The mixture was concentrated, which was poured into water and extracted with $\mathrm{CH}_{2} \mathrm{Cl}_{2}$. The combined organic layers were dried over $\mathrm{MgSO}_{4}$. Solvent was removed in vacuo and the product was purified by recrystallization (ethyl acetate, hexane) to give a white solid. Yield 28\%.

The product was identified by comparing data with literature. $^{2}$

Enantiomeric excess value of product 2 was checked by HPLC analysis equipped with a chiral column. (column: SHISEIDO RU-1; flow rate: $1.0 \mathrm{~mL} / \mathrm{min}$; eluent: $\mathrm{MeOH}$, retention time: $76 \mathrm{~min})$.

${ }^{1} \mathrm{H}-\mathrm{NMR}\left(300 \mathrm{MHz}, \mathrm{CDCl}_{3}\right) \delta 2.02(\mathrm{~s}, 3 \mathrm{H}), 3.05$ (t, 4H, J $=4.6 \mathrm{~Hz}), 3.56-3.65(\mathrm{~m}, 1 \mathrm{H}), 3.68-3.77(\mathrm{~m}, 2 \mathrm{H}), 3.87(\mathrm{t}, 4 \mathrm{H}$, $J=4.4 \mathrm{~Hz}), 4.02$ (t, 1H, $J=9.0 \mathrm{~Hz}), 4.73-4.78(\mathrm{~m}, 1 \mathrm{H}), 6.0$ (brs, 1H), $6.92(\mathrm{t}, 1 \mathrm{H}, J=9.0 \mathrm{~Hz}), 7.08(\mathrm{~d}, 1 \mathrm{H}, J=8.8 \mathrm{~Hz})$, $7.44(\mathrm{dd}, 1 \mathrm{H}, J=2.4,11.9 \mathrm{~Hz})$.

Acknowledgments. This work was financially supported by the grant from the Next Generation BioGreen 21 program [PJ007985], Rural Development Administration, Republic of Korea.

\section{References}

1. (i) Gregory, W. A. U.S. Patent, 4,705,799, November 10, 1987. (ii) Gregory, W. A; Brittelli, D. R.; Wang, C.-L.; Wuonola, M. A.; McRipley, R. J.; Eustice, D. C.; Eberly, V. S.; Bartholomew, P. T.; Slee, A. M.; Forbes, M. J. Med. Chem. 1989, 32, 1673.

2. Brickner, S. J.; Hutchinson, D. K.; Barbachyn, M. R.; Manninen, P. R.; Ulanowicz, D. A.; Garmon, S. A.; Grega, K. C.; Hendges, S. K.; Toops, D. S.; Ford, C. W.; Zurenko, G. E. J. Med. Chem. 1996, $39,673$.

3. Shinabarger, D. I.; Marotti, K. R.; Murray, R. W.; Lin, A. H.; Melchior, E. P.; Swaney, S. M.; Dunyak, D. S.; Demyan, W. F.; Buysse, J. M. Antimicrob. Agents Chemother. 1997, 41, 2132.

4. (i) Grega, K. C.; Barbachyn, M. R.; Brickner, S. J.; Mizsak, S. A. J. Org. Chem. 1995, 60, 5255. (ii) Tucker, J. A.; Allwine, D. A.; Grega, K. C.; Barbachyn, M. R.; Klock, J. L.; Adamski, J. L.; Brickner, S. J.; Hutchinson, D. K.; Ford, C. W.; Zurenko, G. E.; Conradi, R. A.; Burton, P. S.; Jensen, R. M. J. Med. Chem. 1998, 41, 3727.

5. (i) Wang, C.-L.; Gregory, W. A.; Wuonola, M. A. Tetrahedron 1989, 45, 1323. (ii) Reddy, G.M.; Ramulu, A.; Reddy, P. P. Lett. Org. Chem. 2010, 7, 45. (iii) Babu, K. C.; Reddy, R. B.; Gangaiah, L. Madhusudhan, G.; Mukkanti, K. Der Parma Chemica 2011, 3, 219. (iv) Kim, C.; Ko, S.Y. Bull. Korean Chem. Soc. 2011, 32 , 4450

6. (i) Langlois, N.; Moro, A. Eur. J. Org. Chem. 1999, 12, 3483. (ii) Langlois, N. Tetrahedron Lett. 1999, 40, 8801. (iii) Onishi, T.; Hirose, N.; Otake, Y.; Nakano, T.; Honda, Y.; Nakazawa, M.; Izawa, K. EP 1081133 A1. (iv) Crimmins, M. T.; Tabet, E. A. J. Org. Chem. 2001, 66, 4012. (v) Onishi, T.; Hirose, N.; Otake, Y.; Nakano, T.; Honda, Y.; Nakazawa, M.; Izawa, K. EP 1428818 A2. (vi) Arasappan, A.; Njorge, F. G.; Bennett, F.; Girijavallabhan, V. M.; Huang, Y.; Huelgas, R.; Piwinski, J. J.; Shin, N. Y.; Verma, V.; Velazquez, F. WO 2010022121 A1. (vii) Giorgi, G.; Guideri, L.; Ponticelli, F. Tetrahedron 2011, 67, 1463.

7. Klunder, M. K.; Onami, T.; Sharpless, K. B. J. Org. Chem. 1989, $54,1295$.

8. Suryakiran, N.; Prabhakar, P.; Srikanth Reddy, T.; Rajesh, K.; Venkateswarlu, Y. Tetrahedron Lett. 2006, 47, 8039. 